\title{
PENGARUH PENDAPATAN ASLI DAERAH (PAD), DANA PERIMBANGAN TERHADAP PERTUMBUHAN EKONOMI SERTA DAMPAKNYA TERHADAP KEMISKINAN DI KOTA BITUNG
}

\author{
Dewi Chrisanty Paat, Rosalina A.M.Koleangan, Vekie A. Rumate \\ Fakultas Ekonomi dan Binis, Magister Ilmu Ekonomi dan Bisnis \\ Universitas Sam Ratulangi, Manado
}

\begin{abstract}
ABSTRAK
Kota Bitung merupakan kota yang strategis dan mempunyai daya tarik sehingga banyak dilihat oleh investor. Hal ini terlihat dari banyaknya jumlah investasi berupa perusahaan/industri yang masuk Kota Bitung. Dan juga merupakan pelabuhan samudra terbesar di Sulawesi Utara. Dengan banyaknya potensi yang ada di Kota Bitung di harapkan pemerintah kota mampu untuk menggali setiap potensi yang ada guna untuk membangun dan mensejahtrakan masyarakat Kota Bitung. Tujuan dari penelitian ini untuk menganalisis bagaimana pengaruh PAD dan dana perimbangan terhadap pertumbuhan ekonomi serta dampaknya pada kemiskinan di Kota Bitung. Teknik analisis yang digunakan adalah analisis jalur (Path Analysis). Hasil penelitian menunjukan bahwa Pendapatan Asli Daerah (PAD) berpengaruh negatif terhadap pertumbuhan ekonomi akan tetapi tidak berpengaruh secara signifikan. Dana Perimbangan berpengaruh positif terhadap pertumbuhan ekonomi akan tetapi tidak berpengaruh signifikan secara statistik. Pendapatan Asli Daerah (PAD) dan Pertumbuhan Ekonomi berpengaruh negatif terhadap tingkat kemiskinan dan signifikan secara statistik. Dana Perimbangan berpengaruh positif terhadap tingkat kemiskinan di Kota Bitung akan tetapi tidak signifikan secara statistik.
\end{abstract}

\section{Kata Kunci: PAD, Dana Perimbangan, Pertumbuhan Ekonomi dan Tingkat Kemiskinan}

\begin{abstract}
Bitung is a strategic city and has so much appeal seen by investors. This is evident from the large number of investments in the form of companies / industries are entering the city of Bitung. And is also the largest ocean port in North Sulawesi. With so many potential that exists in the city of Bitung in the hope that the municipality is able to explore every potential that exists in order to build and prosperios people in Bitung. The purpose of this study to analyze the influence of the region own source revenue and the balance funds on economic growth and its impact on poverty in the city of Bitung. The analysis technique used is the analysis of the path (Path Analysis). The results showed that the region own source revenue has a negative effect on economic growth but not significantly. Balance Fund has a positive effect on economic growth but not significant statistically. region own source revenue and the Economic Growth negatively affect poverty levels and statistically significant. Balance Fund has a positive effect on the level of poverty in the city of Bitung but not statistically significant.
\end{abstract}

Keyword: Region own source revenue, Balance Of Fund, Economic Growth and Poverty 


\section{PENDAHULUAN}

\section{Latar Belakang}

Pertumbuhan ekonomi merupakan gambaran keadaan perekonomian suatu daerah, pertumbuhan ekonomi yang berkesinambungan merupakan suatu gambaran dari hasil kerja pemerintah baik itu nasional maupun daerah dalam mensejahtrakan dan meningkatkan kemakmuran masyarakat. Pertumbuhan ekonomi yang tinggi diharapkan akan memperbesar kapasitas ekonomi (PDRBProduk Domesti Regional Bruto). Sehingga dengan PDRB yang tinggi maka akan tercipta trickle down effect sehingga kesejahteraan masyarakat akan meningkat. Pembangunan nasional adalah meningkatkan kinerja perekonomian agar mampu menciptakan lapangan kerja dan menata kehidupan yang layak bagi seluruh rakyat yang pada gilirannya akan mewujudkan kesejahteraan penduduk Indonesia. Salah satu sasaran pembangunan nasional adalah menurunkan tingkat kemiskinan.

Pembangunan nasional membutuhkan anggaran belanja pada setiap periode. Seiring dengan peningkatan pembangunan nasional maka anggaran belanja yang diperlukan juga semakin meningkat. Anggaran belanja tersebut didapatkan dari berbagai potensi sumber daya dan pendapatan yang dimiliki oleh suatu daerah. Anggaran pendapatan dan belanja yang didapat digunakan dalam program atau rancangan pemerintah yang disebut Anggaran Pendapatan dan Belanja Daerah (APBD).

Pendapatan asli daerah (PAD) adalah sumber penerimaan daerah asli yang digali di daerah tersebut untuk digunakan sebagai modal dasar pemerintah daerah dalam membiayai pembangunan daerah. Menurut (Pujiati 2008), dengan adanya kewenangan daerah dalam mengoptimalkan PAD, akan memberikan peningkatkan komposisi PAD itu sendiri sebagai penerimaan daerah. Peningkatan PAD yang dianggap sebagai modal, secara akumulasi akan lebih banyak menimbulkan eksternalisasi yang bersifat positif dan akan mempercepat pertumbuhan ekonomi.

Kota Bitung merupakan kota yang strategis dan mempunyai daya tarik sehingga banyak dilihat oleh investor. Hal ini terlihat dari banyaknya jumlah investasi berupa perusahaan/industri yang masuk Kota Bitung. Dan juga merupakan pelabuhan samudra terbesar di Sulawesi Utara. Dengan banyaknya potensi yang ada di Kota Bitung di harapkan pemerintah kota mampu untuk menggali setiap potensi yang ada guna untuk membangun dan mensejahtrakan masyarakat Kota Bitung. Dengan potensi kota Bitung yang begitu besar yang didapat dari sektor perikanan dan kelautan merupakan salah satu daya tarik bagi investor dan juga para pencari kerja baik di dalam maupun luar Kota Bitung.

\section{Tujuan Penelitian}

Untuk mengetahui pengaruh Pendapatan Asli Daerah (PAD), Dana Perimbangan terhadap Pertumbuhan Ekonomi serta dampaknya terhadap Kemiskinan di Kota Bitung.

\section{Landasan Teori}

\section{Pendapatan Asli Daerah}

Pendapatan Asli Daerah (PAD) menurut UU No.33 Tahun 2004 adalah pendapatan yang diperoleh daerah dan dipungut berdasarkan peraturan daerah sesuai dengan peraturan perundang-undangan yang berlaku. PAD merupakan salah satu sumber pendapatan daerah yang 
diperoleh dari sumber-sumber penerimaan di daerah. Pelaksanaan pembangunan di daerah membutuhkan dana yang cukup banyak dan dalam hal ini daerah tidak bisa hanya menggantungkan dana perimbangan dari pusat, sehingga daerah harus dapat menggali potensi daerahnya untuk dapat digunakan sebagai pembiayaan pengeluaran rutin dan pengeluaran pembangunan daerah dalam era otonomi daerah demi meningkatkan pendapatannya.

\section{Dana Perimbangan}

Dana perimbangan adalah dana bersumber dari penerimaan APBN, yang dialokasikan kepada daerah untuk membiayai kebutuhan daerah dalam rangka pelaksanaan desentralisasi. Dana perimbangan terdiri dari (Mardiasmo, 2002): Dana Bagi Hasil, Dana Alokasi Umum (DAU) dan Dana Alokasi Khusus (DAK).

\section{Pertumbuhan Ekonomi}

Simon Kuznet mendefinisikan pertumbuhan ekonomi suatu negara sebagai peningkatan kemampuan suatu negara untuk menyediakan barang-barang ekonomi bagi penduduknya, kenaikan pada kemampuan ini disebabkan oleh adanya kemajuan teknologi, kelembagaan serta penyesuaian ideologi yang dibutuhkannya (Todaro \& Smith, 2012).

\section{Kemiskinan}

Kemiskinan adalah suatu kondisi ketidakmam puan secara ekonomi untuk memen uhi standar hidup rata-rata masyarakat di suatu daerah. Kondisi ketidakmampuan ini ditandai dengan rendahnya kemampuan pendapatan untuk memenuhi kebutuhan pokok baik berupa pangan, sandang, maupun papan. Kemampuan pendapatan yang rendah ini juga akan berdampak berkurangnya kemampuan untuk memenuhi standar hidup rata-rata seperti standar kesehatan masyarakat dan standar pendidikan. Kondisi masyarakat yang disebut miskin dapat diketahui berdasarkan kemampuan pendapatan dalam memenuhi standar hidup (Nugroho, 1995).

\section{METODE PENELITIAN}

\section{Jenis Penelitian}

Jenis penelitian ini adalah kuantitatif yang bersifat untuk mengetahui dampak yang ditimbulkan antara variable Pendapatan Asli Daerah (PAD), Dana Perimbangan terhadap Pertumbuhan Ekonomi dan dampaknya terhadap kemiskinan

\section{Tempat dan Waktu Penelitian}

Tempat penelitian ini adalah Kota Bitung dengan penggambilan data penelitian melalui dinas pendapatan daerah (Dispenda) Kota Bitung. Waktu penelitian adalah dari tahun 20042015.

\section{Metode Analisis}

Metode analisis yang digunakan dalam penelitian ini yaitu analisis jalur. Analisis ini digunakan untuk mengetahui pengaruh variabel independen terhadap variabel dependen melalui variabel intervening. Variabel dependen merupakan variabel yang dipengaruh oleh variabel independen. Variabel independen merupakan variabel yang mempengaruhi variabel lain. 
Sedangkan intervening adalah variabel yang mempengaruhi hubungan antara variabel independen dan variabel dependen menjadi hubungan yang tidak langsung.

\section{Analisis Path}

Pada penelitian ini, peneliti menggunakan analisis jalur (Path Analysis). Analisis jalur ialah suatu teknik untuk menganalisis hubungan sebab akibat yang terjadi pada regres berganda jika variabel bebasnya mempengaruhi variabel tergantung tidak hanya secara langsung tetapi juga secara tidak langsung.

Regresi dikenakan pada masing-masing variabel dalam suatu model sebagai variabel tergantung (pemberi respon) sedangan yang lain sebagai penyebab. Pembobotan regresi diprediksikan dalam suatu model yang dibandingkan dengan matriks korelasi yang diobservasi untuk semua variabel dan dilakukan juga penghitungan uji keselarasan statistik.

\section{Diagram Jalur}

Sesuai dengan judul yang diambil maka berikut ini akan tampilkan model analisi dua jalur dalam gambar 1 sebagai berikut :

\section{Gambar 1 Struktur Model PenelitiaN}

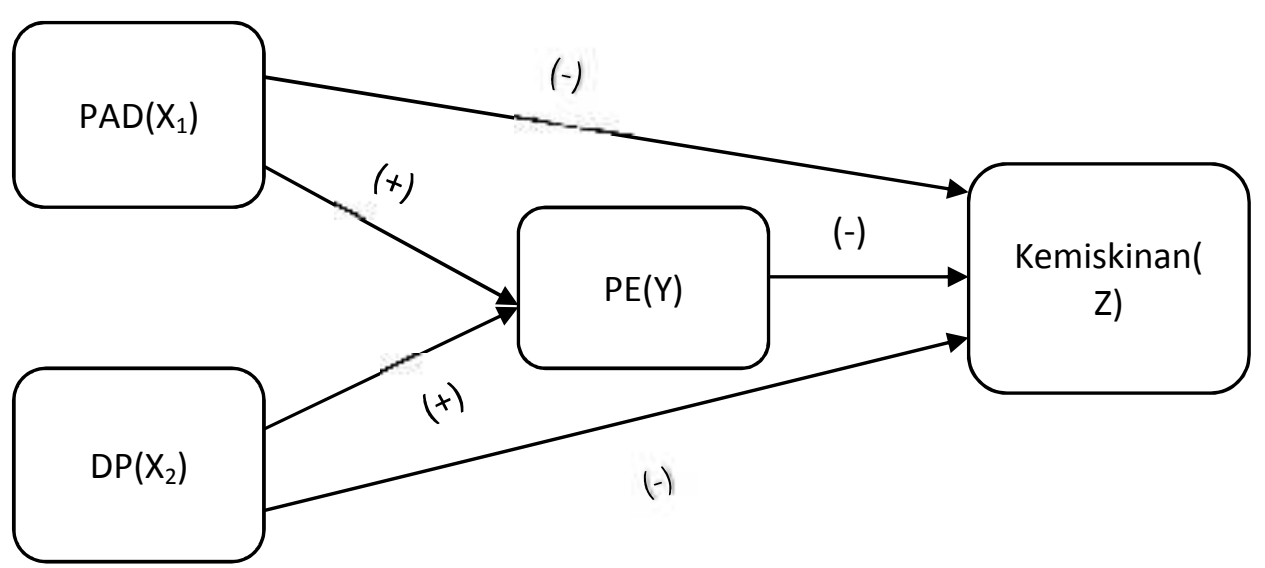

Keterangan :

$\begin{array}{lll}\mathrm{X}_{1} & = & \text { Pendapatan Asli Daerah (PAD) } \\ \mathrm{X}_{2} & = & \text { Dana Perimbangan } \\ \mathrm{Y}_{1} & = & \text { Pertumbuhan Ekonomi } \\ \mathrm{Z}_{1} & = & \text { Tingkat Kemiskinan } \\ \alpha & = & \text { Konstanta/ Intercept } \\ \beta & = & \text { Koefisien Regresi } \\ \mathrm{e} & = & \text { Standar Eror }\end{array}$

Terlihat pada gambar 1 bahwa setiap variabel memiliki hubungan antara lain, baik adanya hubungan secara langsung maupun secara tidak langsung dan memiliki variabel endogen dan eksogen. Pengaruh tidak langsung suatu variabel eksogen terhadap variabel endogen adalah melalui variabel lain yang disebut variabel antara (intervening variable). Dalam gambar 1 variabel PAD dan variabel Dana Perimbangan berpengaruh langsung terhadap 
variabel Pertumbuhan Ekonomi, dan kemudian berpengeruh secara tidak langsung terhadap variabel Tingkat Kemiskinan melalui Pertumbuhan Ekonomi.

\section{HASIL PENELITIAN DAN PEMBAHASAN}

\section{Hasil Estimasi}

Berikut hasil regresi untuk mengetahui Pengaruh Pendapatan Asli Daerah (PAD), Dana Perimbangan terhadap Pertumbuhan Ekonomi dan Dampaknya Terhadap Kemiskinan di Kota Bitung dengan menggunakan metode Path Analysis (analisis jalur). Sesuai dengan pokok permasalahan penelitian ini, maka dapat dilakukan sesuai analisis output SPSS secara berurutan sebagai berikut:

Gambar 2 Hasil Estimasi Struktur Model Penelitian Dua Jalur

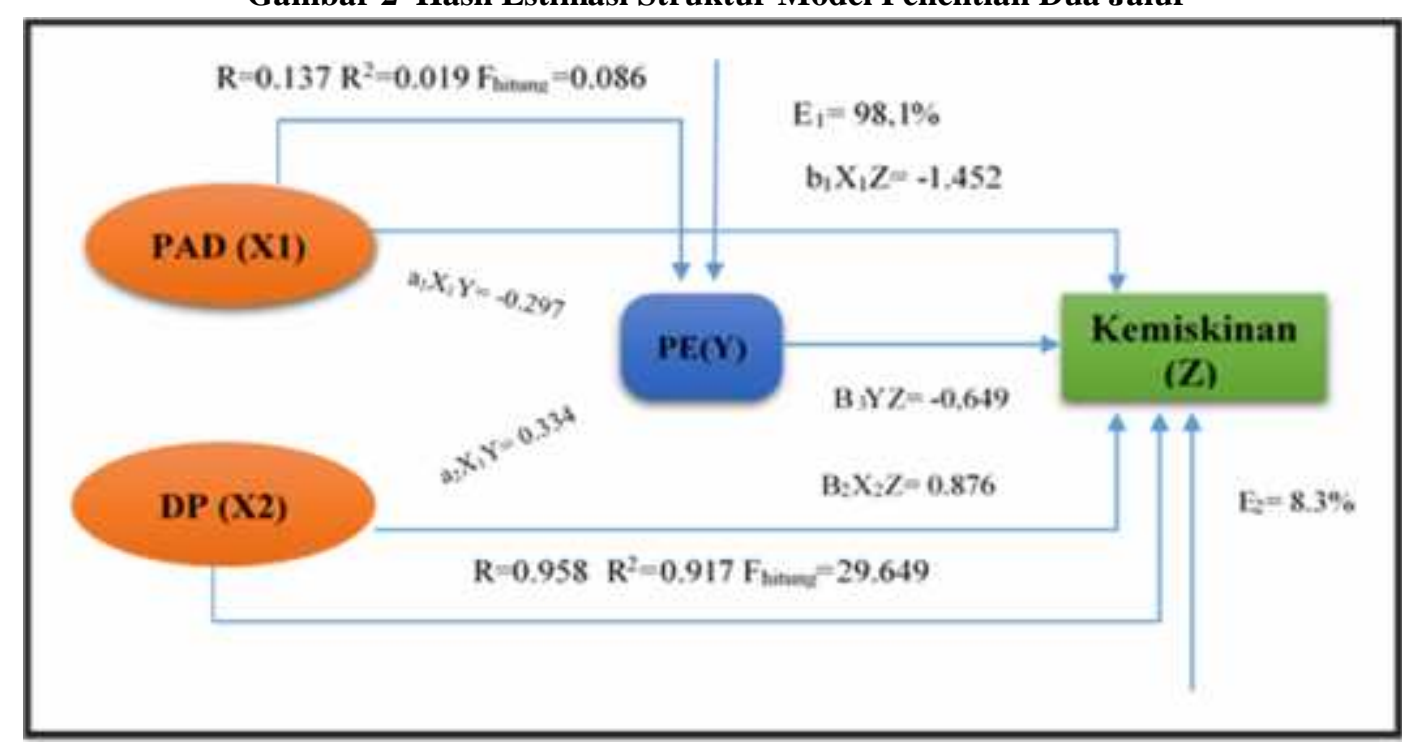

\section{Persamaan Substruktur 1}

$\mathbf{Y}=\mathbf{a}_{1} \mathbf{X}_{1}+\mathbf{a}_{2} \mathbf{X}_{2}+\mathbf{E}_{1}$

$P E_{Y}=-0.297\left(P_{A D}\right)+0.334\left(D_{X 2}\right)+0.981_{E 1}$

Tabel 1 Hasil Regresi Persamaan Substruktur 1

Pendapatan Asli Daerah (PAD) dan Dana Perimbangan (DP) terhadap

Pertumbuhan Ekonomi (PE)

\begin{tabular}{|l|l|l|l|}
\hline Variabel & Coefficient & t- statistic & Probabilitas \\
\hline PAD (X1) & -0.297 & -0.367 & 0.722 \\
\hline DP (X2) & 0.334 & 0.413 & 0.689 \\
\hline$R^{2}=0.019$ & \multicolumn{2}{|c|}{ F- statistic $=0.086$} \\
\cline { 1 - 2 }
\end{tabular}

Sumber : Data olahan SPSS ver. 18

Hasil output SPSS versi 18 diatas, diketahui pada persamaan substruktur 1 dalam model penelitian ini adalah untuk mengetahui dan menguji besar pengaruh nilai Pendapatan Asli 
Daerah (X1) dan Dana Perimbangan (X2) terhadap Pertumbuhan Ekonomi (Y). Hasil estimasi memiliki koefisien determinasi $\left(\mathrm{R}^{2}\right)$ sebesar 0.019 atau $1.9 \%$. Nilai ini memiliki arti bahwa variabilitas Pertumbuhan Ekonomi yang dapat dijelaskan dengan menggunakan variabel Pendapatan Asli Daerah serta Dana Perimbanagan adalah sebesar 1.9\% sedangkan sisanya sebesar $98.1 \%$ dipengaruhi oleh faktor-faktor lain diluar model ini.

Hasil estimasi didapatkan hasil bahwa nilai Pendapatan Asli Daerah (PAD) memiliki pengaruh negatif (-) terhadap nilai Pertumbuhan Ekonomi (PE) sebesar -0.297. Hasil ini tidak sesuai dengan teori yang menyatakan adanya hubungan positif (+) dan mempunyai pengaruh yang tidak segnifikan antara Pendapatan Asli terhadap Pertumbuhan Ekonomi pada tingkat keyakinan 95\%. Hasil dari perhitungan dengan SPSS menunjukan angka t hitung sebesar $0,367<\mathrm{t}$ tabel sebesar 1,833. Dengan demikian keputusanya ialah H0 diterima, dan H1 ditolak. Artinya tidak ada hubungan linier antara Variabel Independen Pendapatan Asli Daerah terhadap Variabel Dependen Pertumbuhan Ekonomi. Maka Variabel Independen Pendapatan Asli Daerah tidak berpengaruh terhadap Variabel Dependen Pertumbuhan Ekonomi. Hal ini menunjukan bahwa kenaikkan Pendapatan Asli Daerah memberikan pengaruh yang negative terhadap Pertumbuhan Ekonomi di Kota Bitung. Hasil ini sejalan dengan penelitian yang dilakukan oleh Prakarsa (2014) Pendapatan Asli Daerah berpengaruh secara tidak signifikan dan berdampak secara negatif terhadap pertumbuhan ekonomi yang ada di Jawa Timur. Ini juga memperlihatkan bahwa penarikan pajak dan retribusi daerah yang dilakukan pemerintah daerah justru menghambat pertumbuhan ekonomi daerah.

Hasil estimasi didapatkan hasil bahwa nilai Dana Perimbangan (DP) memiliki pengaruh positif $(+)$ terhadap nilai Pertumbuhan Ekonomi (PE) sebesar 0.334. Hasil ini sesuai dengan teori yang menyatakan adanya hubungan positif $(+)$ antara ke duanya. Akan tetapi, nilai Dana Perimbangan tersebut mempunyai pengaruh yang tidak signifikan terhadap Pertumbuhan Ekonomi pada tingkat keyakinan 95\%. Hasil dari perhitungan dengan SPSS menunjukan angka $\mathrm{t}$ hitung sebesar $0.689<\mathrm{t}$ tabel sebesar 1,833. Dengan demikian keputusanya ialah H0 diterima, dan H1 ditolak. Artinya tidak ada hubungan linier antara Variabel Independen Dana Perimbangan terhadap Variabel Dependen Pertumbuhan Ekonomi. Maka Variabel Independen Dana Perimbangan tidak berpengaruh terhadap Variabel Dependen Pertumbuhan Ekonomi. Hasil ini mendukung penelitian yang di lakukan oleh Azzumar (2011) menyatakan bahwa Dana Perimbangan berpengaruh positif terhadap pertumbuhan ekonomi, akan tetapi tidak berpengaruh terhadap peningkatan pertumbuhan ekonomi.

Pemerintah terus berupaya untuk semakin meningkatkan kesejahteraan masyarakat dengan meneruskan dan lebih memaksimalkan usaha-usaha penanggulangan kemiskinan di Kota Bitung lewat berbagai program yang dilaksanakan baik oleh Tim Koordinasi Penanggulangan Kemiskinan Daerah (TKPKD) dan SKPD Kota Bitung yaitu berbagai kegiatan pemberdayaan usaha kecil menengah dan koperasi, pengembangan dan penguatan kelompok tani, peningkatan ketrampilan dan kapasitas tenaga kerja, peningkatan daya saing produksi serta perbaikan dan pembangunan infrastruktur pertanian, kebijakan revitalisasi pertanian perkebunan dan kehutanan.

Secara keseluruhan, variabel nilai Pendapatan Asli Daerah dan Dana Perimbangan mempunyai pengaruh yang tidak signifikan terhadap nilai Pertumbuhan Ekonomi. Hal ini ditunjukkan oleh nilai $\mathrm{F}_{\text {stat }}$ sebesar 0.086 yang lebih kecil daripada nilai $\mathrm{F}_{\text {tabel }}$ sebesar 4.26 pada tingkat keyakinan $95 \%$. 


\section{Persamaan Substruktur 2}

$$
\begin{aligned}
& Z_{1}=b_{1} X_{1}+b_{2} X_{2}+b_{3} Y_{1}+e_{t} \\
& \text { Kemiskinan }=-1.673\left(P_{A} D_{X 1}\right)+1.161\left(D_{X_{2}}\right)-0.320(P E)+0,087
\end{aligned}
$$

Tabel 2 Hasil Regres Persamaan Substuktur 2

Pendapatan Asli Daerah (PAD), Dana Perimbangan (DP) dan Pertumbuhan Ekonomi (PE)

Terhadap Kemiskinan (K)

\begin{tabular}{|l|l|l|l|}
\hline Variabel & Coefficient & t- statistic & Probabilitas \\
\hline PAD (X1) & -1.452 & -5.793 & 0.000 \\
\hline DP (X2) & 0.876 & 3.490 & 0.008 \\
\hline PE (Y) & $-0.649 \quad-6.329$ & 0.000 \\
\hline $\mathrm{R}^{2}=0.917$ & F- statistic $=29.649$ \\
\hline
\end{tabular}

Hasil estimasi memiliki koefisien determinasi (R2) sebesar 0,917 atau 91.7\%. Nilai ini memiliki arti bahwa variabilitas Kemiskinan yang dapat dijelaskan dengan menggunakan variabel Pendapatan Asli Daerah, Dana Perimbangan dan Pertumbuhan Ekonomi adalah sebesar $91.7 \%$, sedangkan sisanya sebesar 8,7\% dipengaruhi oleh faktor-faktor lain diluar model ini.

Hasil estimasi, didapatkan hasil bahwa nilai Pendapatan Asli Daerah (PAD) memiliki pengaruh negative (-) terhadap Kemiskinan sebesar -1.452 .Hasil ini ternyata sesuai dengan teori yang menyatakan adanya hubungan negatif (-) dan mempunyai pengaruh yang signifikan terhadap Kemiskinan pada tingkat keyakinan 99\%. Hasil dari perhitungan dengan SPSS menunjukan angka $\mathrm{t}$ hitung sebesar $5.793>\mathrm{t}$ tabel sebesar 2.896. Dengan demikian keputusanya adalah H0 ditolak, dan H1 diterima. Artinya ada hubungan linier antara Variabel Independen Pendapatan Asli Daerah terhadap Variabel Dependen Kemiskinan. Hasil ini sejalan yang dilakukan oleh Musliadi (2013) yang menjelaskan bahwa Pendapatan Asli Daerah berpengaruh negatif dan signifikan terhadap Kemiskinan di Provinsi Aceh dan Titisari (2012) tentang analisis pendidikan dan pendapatan asli daerah terhadap kemiskinan pada era otonomi daerah di Jawa Tengah Pada Tahun 2007-2009 menunjukan bahwa pendidikan dan pendapatan asli daerah mempunyai pengaruh negatif dan signifikan terhadap kemiskinan pada era otonomi daerah.

Pengaruh tidak langsung variabel Pendapatan Asli Daerah dan Kemiskinan melalui Pertumbuhan Ekonomi $\left(\mathrm{X}_{1}-\mathrm{Z}-\mathrm{Y}\right)$. Pendapatan Asli Daerah memiliki pengaruh yang secara tidak langsung terhadap Kemiskinan sebesar 0.19275. Hubungan negatif antara Pendapatan Asli Daerah terhadap kemiskinan memiliki pengaruh yang signifikan secara statistik.

Hasil estimasi didapatkan bahwa Dana Perimbangan (DP) memiliki pengaruh positif (+) terhadap Kemiskinan sebesar 0.876. Hasil ini tidak sesuai dengan teori yang menyatakan adanya hubungan positif (-). Akan tetapi, mempunyai pengaruh yang signifikan terhadap kemiskinan pada tingkat keyakinan 99\%. Hasil dari perhitungan dengan SPSS menunjukan angka t hitung sebesar $3.490>\mathrm{t}$ tabel sebesar 2.896. Dengan demikian keputusanya adalah H0 ditolak, dan H1 
diterima. Artinya ada hubungan linier antara Variabel Independen Dana Perimbangan terhadap Variabel Dependen Kemiskinan. Walaupun ada kenaikan kemiskinan akibat dari adanya keinakan Dana Perimbangan dari pemerintah pusat akan tetapi tidak berpengaruh signifikan.

Pengaruh tidak langsung variabel Dana Perimbangan Daerah dan Kemiskinan melalui Pertumbuhan Ekonomi $\left(\mathrm{X}_{2}-\mathrm{Z}-\mathrm{Y}\right)$. Dana Perimbangan memiliki pengaruh yang secara tidak langsung terhadap Kemiskinan sebesar 0.21476. Hubungan positif antara Dana Perimbangan terhadap kemiskinan memiliki pengaruh yang signifikan secara statistik.

Hasil estimasi didapatkan bahwa Pertumbuhan Ekonomi (PE) memiliki pengaruh negative (-) terhadap kemiskinan sebesar -0.469 dan berpengaruh secara signifikan terhadap kemiskinan pada tingkat keyakinan 95\%. Hasil dari perhitungan dengan SPSS menunjukan angka $t$ hitung sebesar 6.329 > t tabel sebesar 1.833. Dengan demikian keputusanya adalah H0 ditolak, dan H1 diterima. Artinya ada hubungan linier antara Variabel Independen Pertumbuhan Ekonomi terhadap Variabel Dependen Kemiskinan. Penelitian ini mendukung penelitian yang dilakukan oleh Nurdin (2009) yang menemukan bahwa pertumbuhan ekonomi tidak berpengaruh langsung terhadap kemiskinan daerah perkotaan dan Hamzah (2007) yang menunjukan bahwa pertumbuhan ekonomi berpengaruh negatif terhadap kemiskinan.

Secara keseluruhan, ketiga variabel Pendapatan asli Daerah (PAD), Dana Perimbangan (DP), dan Pertumbuhan Ekonomi (PE) mempunya nilai yang signifikan terhadap Kemiskinan. Hal ini ditunjukkan olaeh nilai $\mathrm{F}_{\text {stat }}$ sebesar 28,063 lebih besar daripada nilai $\mathrm{F}_{\text {tabel }}$ sebesar 7.59 pada tingkat keyakinan $99 \%$.

Dalam rangka upaya untuk semakin lebih memaksimalkan usaha-usaha penanggulangan kemiskinan di kota Bitung antara lain melalui berbagai program kegiatan sebagai berikut : Program Keluarga Harapan (PKH), Program Nasional Pemberdayaan Masyarakat (PNPM) Mandiri Perkotaan, Program Pelayanan / Jaminan Kesehatan bagi masyarakat miskin (Jamkesmas dan Jamkesda), Program bantuan / Jaminan Beras MIskin (Raskin), Program Pemberdayaan Koperasi dan UKM, Program Bantuan Perumahan dan Program pengembangan Usaha Mina pedesaan Perikanan Tangkap dan Perikanan Budidaya.

\section{Korelasi Antar Variabel}

Berdasarkan hasil estimasi, diketahui bahwa korelasi antar variabel Pendapatan Asli Daerah (PAD) dan Dana Perimbangan (DP) terhadap Kemiskinan secara individual sebagai berikut.

Tabel 3 Korelasi pada Persamaan Substruktur 1

\begin{tabular}{|l|l|l|l|}
\hline Variabel & PAD & DP & PE \\
\hline PAD & 1 & 0.913 & 0.008 \\
\hline DP & 0.913 & 1 & 0.063 \\
\hline PE & 0.008 & 0.063 & 1 \\
\hline
\end{tabular}

Sumber : Data olahan SPSS Ver.18

1) Korelasi anatar PAD dan DP sebesar $\left(r_{1}\right) 0.913$ kriteria positif dengan signifikansi sebesar 0,000 atau $0 \%$ yang berarti sangat signifikan.

2) Korelasi antara PAD dan PE sebesar $\left(\mathrm{r}_{2}\right) 0.008$ kriteria positif dengan signifikansi sebesar 0,980atau $98 \%$ berarti tidak signifikan.

3) Korelasi antara DP dan PE sebesar $\left(\mathrm{r}_{3}\right)$ 0,063 kriteria positive dengan signifikansi sebesar 0,846 atau $84.6 \%$ berarti tidak signifikan. 


\section{Korelasi Secara Keseluruhan}

Berdasarkan hasil estimasi, diketahui bahwa korelasi antar variabel Pertumbuhan Ekonomi (PE) dan Kemiskinan secara keseluruhan sebagai berikut.

Tabel 4 Korelasi pada Persamaan Substruktur 2

\begin{tabular}{|l|l|l|l|l|}
\hline Variabel & PAD & DP & PE & Kemiskinan \\
\hline PAD & 1 & 0.913 & 0.008 & -0.657 \\
\hline DP & 0.913 & 1 & 0.063 & -0.490 \\
\hline PE & 0.008 & 0.063 & 1 & -0.605 \\
\hline Kemiskinan & -0.657 & -0.490 & -0.605 & 1 \\
\hline
\end{tabular}

Sumber : Data olahan SPSS Ver.18

1. Korelasi antara PAD dan Kemiskinan sebesar $\left(\mathrm{r}_{1}\right)-0,657$ kriteria negatif dengan signifikansi sebesar 0,020 atau $20 \%$ yang berarti tidak signifikan hubungan kedua variabel tersebut

2. Korelasi antara DP dan Kemiskinan sebesar $\left(\mathrm{r}_{1}\right)-0,490$ kriteria negatif dengan signifikansi sebesar 0,106 atau $10.6 \%$ yang berarti tidak signifikan hubungan kedua variabel tersebut

3. Korelasi antara PE dan Kemiskinan sebesar $\left(\mathrm{r}_{1}\right)-0,605$ kriteria negatif dengan signifikansi sebesar 0,037 atau $37 \%$ yang berarti tidak signifikan hubungan kedua variabel tersebut

\section{KESIMPULAN DAN SARAN}

\section{Kesimpulan}

1. Hasil estimasi didapatkan hasil bahwa nilai Pendapatan Asli Daerah (PAD) berpengaruh negatif terhadap pertumbuhan ekonomi akan tetapi tidak berpengaruh secara signifikan. Dana Perimbangan berpengaruh positif terhadap pertumbuhan ekonomi akan tetapi tidak berpengaruh signifikan secara statistik. Hal ini menunjukan bahwa peningkatan Pendapatan Asli Daerah dan Dana Perimbangan belum bisa memberikan pengaruh yang signifikan terhadap peningkatan laju pertumbuhan ekonomi di Kota Bitung.

2. Hasil estimasi didapatkan bahwa Pendapatan Asli Daerah (PAD) dan Pertumbuhan Ekonomi berpengaruh negatif terhadap tingkat kemiskinan dan signifikan secara statistik. Hal ini menunjukan bahwa Pendapatan Asli Daerah dan Pertumbuhan Ekonomi mampu menekan tingkat kemiskinan di Kota Bitung. Dana Perimbangan berpengaruh positif terhadap tingkat kemiskinan di Kota Bitung akan tetapi tidak signifikan secara statistik. Walaupun ada kenaikan kemiskinan akibat dari adanya keinakan Dana Perimbangan dari pemerintah pusat akan tetapi tidak berpengaruh signifikan. 


\section{Saran}

Bagi Pemerintah kota Bitung agar lebih memaksimalkan lagi potensi-potensi penerimaan daerah dari sisi sektor perikanan dan kelautan dan agar bisa memberikan kondisi yang aman dan nyaman bagi setiap investor dan perusahan/industri dan juga bisa memberikan lapangan pekerjaan kepada masyarakat yang ada di kota Bitung yang nantinya dapat berkontribusi baik secara langsung maupun tidak langsung terhadap pertumbuhan perekonomian dan diharapkan nantinya akan mengurangi tingkat kemiskinan di Kota Bitung.

\section{Paper dalam Jurnal}

\section{DAFTAR PUSTAKA}

[1] Azzumar, Rizky Mochmed. 2011. Pengaruh Pendapatan Asli Daerah, InvestasiSwasta dan Tenaga Kerja Terhadap Pertumbuhan Ekonomi. Skripsi.Universitas Diponegoro Semarang.

[2] Febrian Dwi Prakarsa 2014. Analisis pengaruh pendapatan asli Daerah dan pengeluaran pemerintahdaerah terhadap pertumbuhan ekonostudi kasus di kabupaten kota jawa timur tahun 2008-2012.

[3] Hamzah, A. S. (2007). Analisis Pengaruh Pendapatan Asli Daerah, Dana Alokasi Umum,

Dana Alokasi Khusus, dan Belanja Pembangunan Terhadap Pertumbuhan Ekonomi, Kemiskinan, dan Pengangguran: Pendekatan Analisis Jalur. Jurnal Akuntansi dan Keuangan Indonesia 4 (2):211-228.

[4] Musliadi. (2013). Analisis Pengaruh Dana Otonomi Khusus, Pendapatan Asli Daerah Dan Belanja Modal Terhadap Kemiskinan Pada Kabupaten/ Kota Di Provinsi Aceh Tahun 2008-2012. Yogyakarta: Tesis Universitas Gajah Mada.

[5] Nurdin, A. H. (2009). Pengaruh Anggaran Pemberdayaan Ekonomi Masyarakat Dalam APBD Kotadan Desentralisasi Fiskal Terhadap Kemiskinan Daerah Perkotaan Di Indonesia.

[6] Titisari, E. W. (2012). Analisis Pendidikan dan Pendapatan Asli Daerah Terhadap Kemiskinan Pada Era Otonomi Daerah Di Jawa Tengah Pada Tahun 2007-2009. Semarang: Skripsi Universitas Negeri Semarang.

\section{Buku}

[1] Mardiasmo. 2002. Otonomi dan Manajemen Keuangan Daerah. Andi: Yogyakarta

[2] Todaro, M.P dan Smith, Stephen C, 2004, Pembangunan Ekonomi di Dunia Ketiga, Penerbit Erlangga, Jakarta.

[3] Agung Nugroho, 2005. Strategi Jitu memilih Metode statistic Penelitian dengan SPSS, Andi Jogyakart 